\title{
A Possible Mechanism in Interaction of a Partial Agonist with $\beta$-Adrenoceptor in Guinea-Pig Taenia Caecum: Effects of Gpp(NH)p on Its Two Different Binding Sites
}

\author{
Katsuo KOIKE and Issei TAKAYANAGI* \\ Department of Chemical Pharmacology. Toho University School of \\ Pharmaceutical Sciences, Miyama. Funabashi, Chiba 274, Japan \\ Accepted March 1. 1985
}

\begin{abstract}
The mechanisms of the actions of the $\beta$-adrenergic partial agonist (befunolol) were studied in isolated guinea-pig taenia caecum. Befunolol, 2 -acetyl7-(2-hydroxy-3-isopropylaminopropoxy) benzofuran hydrochloride was found to be a typical partial agonist in guinea-pig taenia caecum. The $\mathrm{pD}_{2}$-value of befunolol was in agreement with its $p K_{A}$-value obtained with photoaffinity labeling, but was different from its $\mathrm{pA}_{2}$-value against isoprenaline and $\mathrm{pK}$-value obtained from the inhibition of specific $\left[{ }^{3} \mathrm{H}\right]$-dihydroalprenolol binding. The Scatchard plot of the specific $\left[{ }^{3} \mathrm{H}\right]$-befunolol binding showed two affinity sites of the receptor in the absence of $\mathrm{Gpp}(\mathrm{NH}) \mathrm{p}$, but the low affinity site was reduced while the high affinity site was not affected in the presence of Gpp(NH)p. The $\mathrm{pK}_{1}$-value of the high affinity site of befunolol was in agreement with its $p A_{2}$-value, and the $p K_{1}$-value of the low affinity site was in agreement with its $p D_{2}$-value or $p K_{A}$-value. These results suggest that the $\beta$-adrenergic partial agonist may interact with two different sites: an agonist binding site and an antagonist binding site.
\end{abstract}

Since a partial agonist has an affinity to its receptors and an intrinsic activity which lies somewhere between that $(=1)$ of a full agonist and that $(=0)$ of a competitive antagonist (1.2), the partial agonist has both agonistic and antagonistic actions (3).

In the previous papers $(4,5)$, we studied the mode of action of the $\beta$-adrenergic partial agonist carteolol in the guinea-pig taenia caecum. Indexes for agonistic activities. $\mathrm{pD}_{2}$-values of the $\beta$-adrenergic partial agonist carteolol obtained in the mechanical response and in the increase of cyclic AMP concentration, were significantly different from its indexes for antagonistic activities, $\mathrm{pA}_{2}$-values obtained in the mechanical response and in the increase of cyclic AMP concentration and also the $p K_{i}$-value (negative log of its apparent dissociation constant) obtained in binding experiments. Moreover, our previous findings were con-

\footnotetext{
* To whom reprint requests should be addressed.
}

firmed with some $\beta$-adrenergic partial agonists (6). Therefore, these results suggest that an interaction of a partial agonist with the $\beta$-adrenoceptor cannot be understood by the classical receptor theory. Recently. many investigators have found that in studies of the radioligand binding to $\beta$-adrenoceptor or other membrane receptors, guanine nucleotides cause a selective reduction in agonist binding, while having only a minimal effect in antagonist binding $(7,8)$.

Since befunolol (Kaken Pharmaceutical Co., Japan), 2-acetyl-7-(2-hydroxy-3-isopropylaminopropoxy) benzofuran hydrochloride (Fig. 1), was found to be a $\beta$ adrenergic partial agonist in guinea-pig taenia caecum in this study, in order to study mechanisms of the actions of the $\beta$ adrenergic partial agonist, we tested the relationship between the mechanical response of befunolol and radioligand binding using $\left[{ }^{3} \mathrm{H}\right]$-befunolol to microsomal fractions in the presence or absence of a guanosine 5'- 


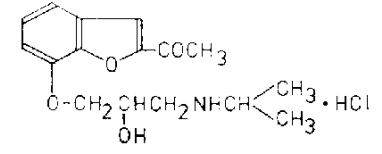

2-Acetyl-7-(2-hydroxy-3-iso propylaminooropoxy) benzofurar hydrochloride

(Betunolol hydrochloride)

Fig. 1. Chomical stucture of befunol

triphosphate (GTP) analogue, guanyl $5^{\circ}-y \mid$ imidodiphosphate, $\mathrm{Gpp}(\mathrm{NH}) \mathrm{p}$.

\section{Materials and Methods}

Mechanical response: Male guinea-pigs weighing $300-350 \mathrm{~g}$ were killed by a blow on the head. A piece $(3 \mathrm{~cm})$ of the isolated taenia caecum was suspended in a $20 \mathrm{ml}$ organ bath filled with Locke-Ringer solution $\left(\mathrm{NaCl}, 154 ; \mathrm{KCl}, 5.6 ; \mathrm{CaCl}_{2}, 2.2 ; \mathrm{MgCl}_{2}, 2.1\right.$ : $\mathrm{NaHCO}_{3}, 5.9$; and glucose, $2.8 \mathrm{mM}$ ) kept at $32^{\circ} \mathrm{C}$ and bubbled with air. The mechanical responses of the preparations were recorded isotonically. The dose-response curves of test drugs were obtained cumulatively (9). and the relaxation induced by test drugs was expressed as percentage of the amplitude of the maximum relaxation produced by test drugs. In order to test the antagonism between isoprenaline and befunolol, befunolol was added to the bath 5 min before the addition of isoprenaline. Activity of the agonist was expressed as the $\mathrm{pD}_{2}$-value (9). Activity of a competitive antagonist was also expressed as the $\mathrm{pA}_{2}$-value. The $\mathrm{pA}_{2}$-value was calculated from the parallel shift of the curve of the agonist, according to the table of van Rossum (9).

Photoaffinity labeling of the $\beta$-adrenoceptors with isoprenaline: $A$ piece $(3 \mathrm{~cm})$ of the isolated guinea-pig taenia caecum was horizontally set in a $10 \mathrm{ml}$ organ bath filled with Locke-Ringer solution, kept at $32^{\circ} \mathrm{C}$ and bubbled with air. Responses to drugs were recorded isotonically. A Toshiba lamp FL-20E (wavelength: $270-350 \mathrm{~nm}$ ) was used as a light source, and the preparation was irradiated at $2 \mathrm{~cm}$ under the lamp, as reported previously $(10,11)$. The doseresponse curves of test drugs were obtained cumulatively (9).

The dissociation constants were calculated by the method of Furchgott (12). The following equation was applied to the results:

$$
\frac{1}{(A)}=\frac{1-q}{q\left(K_{A}\right)}+\frac{1}{q\left(A^{\prime}\right)}
$$

where $q$ is the fraction of active receptors remaining after irradiation. The equiactive molar concentrations of befunolol obtained before (A) and after irradiation ( $A^{\prime}$ ) were obtained from individual experiments. The reciprocal values were plotted as $1 /(A)$ vs. $1 /\left(A^{\prime}\right)$, and the dissociation constants $\left(K_{A}\right)$ were calculated as: $K_{A}=($ slope-1)/intercept.

Preparation of microsomal fractions: Male guinea-pigs weighing $300-350 \mathrm{~g}$ were killed, and the taenia caecum was rapidly removed and washed with an ice-cold medium containing $0.25 \mathrm{M}$ sucrose and $10 \mathrm{mM}$ Tris $/ \mathrm{HCl}\left(\mathrm{pH} 7.4\right.$ at $\left.4^{\circ} \mathrm{C}\right)$. The isolated tissues were minced with scissors and homogenized with a Polytron homogenizer (Kinematica) in $20 \mathrm{vol}$. of $0.25 \mathrm{M}$ sucrose containing $10 \mathrm{mM}$ Tris $/ \mathrm{HCl}(\mathrm{pH} 7.4$ at $4^{\circ} \mathrm{C}$ ) with the rheostat setting 9 for $5 \mathrm{sec}$ The homogenate was centrifuged at $2,500 \mathrm{~g}$ for $10 \mathrm{~min}$. The supernatant was again centrifuged at $15,000 \mathrm{~g}$ for $20 \mathrm{~min}$. Centrifugation of the supernatant at $100,000 \mathrm{~g}$ for 60 min resulted in a pellet which was used as the microsomal fractions in this study (13).

Protein concentrations were determined by the method of Lowry et al. (14) using bovine serum albumin as a standard.

Binding assay: Microsomal fractions were incubated with various concentrations of $\left[{ }^{3} \mathrm{H}\right]$-befunolol in a total volume of $150 / \mu$ of incubation buffer $(50 \mathrm{mM}$ Tris $/ \mathrm{HCl}, \mathrm{pH} 7.4$ at $35^{\circ} \mathrm{C}$ ) for $15 \mathrm{~min}$. The incubation mixture was diluted with $1 \mathrm{ml}$ of $50 \mathrm{mM}$ Tris/ $\mathrm{HCl}(\mathrm{pH}$ 7.4) and rapidly filtered through Whatman GF/C glass fiber filters. The filters were washed 3 times with $3 \mathrm{ml}$ of ice-cold $50 \mathrm{mM}$ Tris $/ \mathrm{HCl}(\mathrm{pH} \mathrm{7.4)}$. After the passage, the filters were dried and radioactivity was determined in a toluene base scintillator with liquid scintillation spectrometer (Aloka LSC900).

Nonspecific binding was determined as radioactivity bound to microsomal fractions which are not displaced by $5 \mu \mathrm{M}$ propranolol.

In order to test the effects of $\mathrm{Gpp}(\mathrm{NH}) \mathrm{p}$ on the affinity of befunolol to $\beta$-adrenoceptor. 
the specific $\left[{ }^{3} \mathrm{H}\right]$-befunolol binding to microsomal fractions was obtained in the presence or absence of Gpp(NH)p $100 / \mathrm{M}$.

Data was analyzed by iterative nonlinear regression analysis using a $\mathrm{PC}-9801 \mathrm{F2}$ (NEC. Tokyo), with the program "WBSIKK" (15).

The $50 \%$ inhibition concentration (IC50 value) of befunolol for inhibiting the binding of $\left[{ }^{3} \mathrm{H}\right]$-dihydroalprenolol $(10 \mathrm{nM})$ to microsomal fractions was experimentally estimated. The apparent dissociation constant $\left(\mathrm{K}_{\mathrm{i}}\right.$ value) was calculated by the following equation: $K_{i}=I C 50 /\left(1+L / K_{1}\right)$ (16). where $L$ is the concentration of $\left[{ }^{3} \mathrm{H}\right]$-dihydroalprenolol (10 nM).

Drugs used: Drugs used were as follows: befunolol hydrochloride (Kaken Pharmaceutical Co.): isoprenaline hydrochloride. propranolol hydrochloride, Tris, $\operatorname{Gpp}(\mathrm{NH}) \mathrm{p}$ (Sigma): [ $\left.{ }^{3} \mathrm{H}\right]$-dihydroalprenolol (sp. act. $40.6 \mathrm{Ci} / \mathrm{mmol}$ ) and $\left[{ }^{3} \mathrm{H}\right]$-befunolol (sp. act: $115.0 \mathrm{Ci} / \mathrm{mmol}$ ) (New England Nuclear). Other chemicals used were of analytical grade.

\section{Results}

The dose-response curves for isoprenaline and befunolol are shown in Fig. 2. Intrinsic activities (mean $\pm S . E ., N=6$ ) of these drugs were 1.0 for isoprenaline, which is a reference drug, and $0.28 \pm 0.03$ for befunolol. The $\mathrm{pD}_{2}-$ values (mean \pm S.E., $N=6$ ) were $8.59 \pm 0.06$ for isoprenaline and $7.06 \pm 0.16$ for befunolol. Figure 3 shows that befunolol $\left(10^{-9}\right.$ and $10^{-8}$ M) shifted dose-dependently the dose-

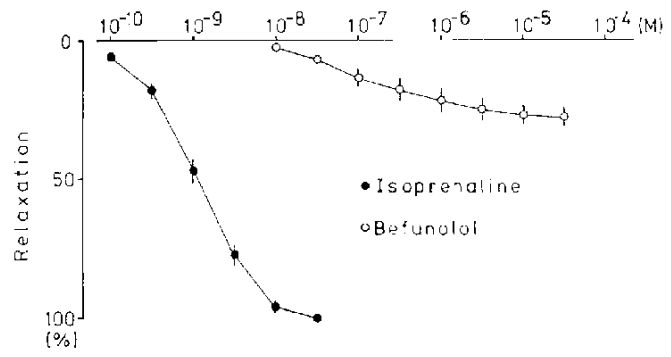

Fig. 2. Relaxatiun of the guinea-pig taenia caecum produced by isoprenaline and befunolol. Percent response for befunolol was calculated as a percentage of the maximum relaxation produced by isoprenaline. Each point is presented as a mean with S.E. (bar) of 6 experiments. Abscissa: dose of drug (M) and ordinate: relaxation $(\%)$. response curve of isoprenaline towards higher doses, even though $10^{-9}$ and $10^{-8} \mathrm{M}$ of befunolol did not induce an agonistic effect. The $\mathrm{pA}_{2}$-value (mean \pm S.E., $\mathrm{N}=6$ ) for befunolol was $9.22 \pm 0.10$.

Photoaffinity labeling of the $\beta$-adrenoceptor by the $25 \mathrm{~min}$ irradiation with isoprenaline $\left(6 \times 10^{-6} \mathrm{M}\right)$ was done. The effect of photo-inactivation of the receptor on the dose-response curve of befunolol is shown in Fig. 4. The negative log of the dissociation constant, $p K_{A}$-value of befunolol $(6.88 \pm 0.32, N=6)$ was in agreement with

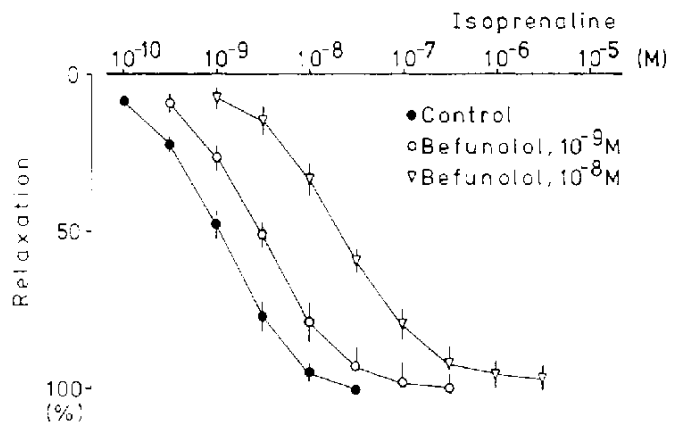

Fig. 3. Effects of befuriolol $\left(10^{-9}\right.$ and $\left.10^{-8} \mathrm{M}\right)$ on the dose-response curve of isoprenaline in the gunnea-pig taenia caecum. Each point is presented as a mean with S.E. (bar) of 6 experiments. Abscissa: dose of isoprenaline (M) and ordinate: rolaxation $\%$.

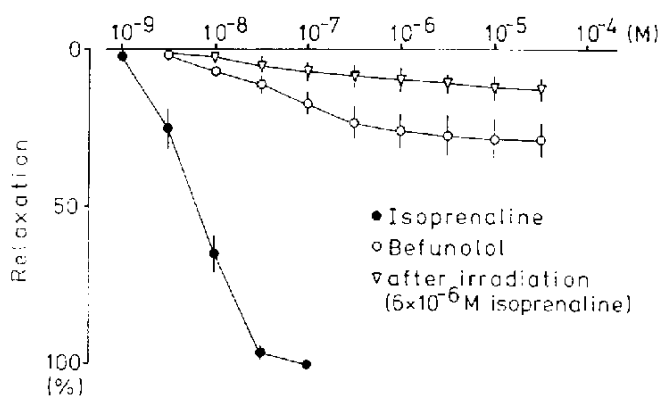

Fig. 4. Effect of irradiation on the dose-response curve of befunolol in the guinea-pig taenia caecum.

- Isoprenaline: $O$. befunolol: $\nabla$, after the $25 \mathrm{~min}$ incubation of the taenia with $6 \times 10^{-6} \mathrm{M}$ isoprenaline following irradiation and washing the taenia with Locke-Ringer solution for $2 \mathrm{hr}$. Each point is prescnted as a mean with S.E. (bar) of 6 experiments. Abscissa dose of drug $(M)$ and ordinate: relaxation $(\%)$. 
its $\mathrm{pD}_{2}$-value $(7.06 \pm 0.16, \mathrm{~N}=6)$, but not with its $\mathrm{pA}_{2}$-value $(9.22 \pm 0.10, N=6)$.

Inhibition of $\left[{ }^{3} \mathrm{H}\right]$-dihydroalprenolol binding to microsomal fractions from the guineapig taenia caecum by befunolol are shown in Fig. 5. The dissociation constant $\left(K_{i}\right)$ and the maximum binding site $\left(\mathrm{B}_{\max }\right)$ of $\left[{ }^{3} \mathrm{H}\right]$ dihydroalprenolol used in this study were $6.67 \mathrm{nM}$ and $90.13 \mathrm{fmoles} / \mathrm{mg}$ protein. respectively, as previously reported $(4,5)$. The negative log of the apparent dissociation constant ( $p K_{1}$-value; mean \pm S.E., $N=4$ ) for befunolol was $9.17 \pm 0.13$. The Hill plot of befunolol obtained from the inhibition curves was linear, and its slope (Hill's coefficient; mean \pm S.E., $N=4$ ) was $1.03 \pm 0.23$. The apparent dissociation constant ( $p K_{i}$-value) of befunolol (9.17 $\pm 0.13, N=4$ ) was in agreement with its $\mathrm{pA}_{2}$-value $(9.22 \pm 0.10, N=6)$ obtained in the mechanical response, but was different from its $\mathrm{pD}_{2}$-value $(7.06 \pm 0.16$,

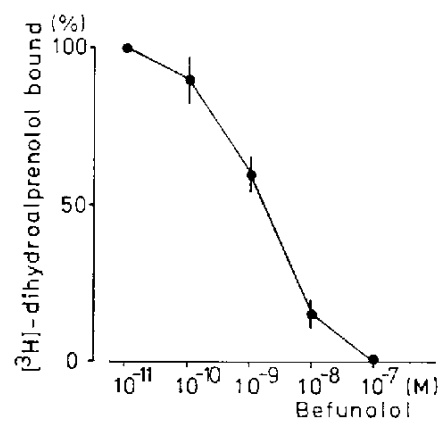

Fig. 5. Inhibition of $\left[{ }^{3} \mathrm{H}\right]$-dihydroalprenolol binding to microsomal fractions from the guinea-pig taenia caecum by befunolol. Various concentrations of befunolol were used to inhibit $\left[{ }^{3} \mathrm{H}\right]$ dihydroalprenolol binding. Each point is presented as a mean $\pm S$.E. (bar) of 4 separate experiments.
$N=6)$ obtained in the mechanical response and the $\mathrm{pK}_{\mathrm{A}}$-value $(6.88 \pm 0.32, \quad \mathrm{~N}=6)$ obtained with photoaffinity labeling.

Figure $6 \mathrm{~A}$ shows the typical specific binding of $\left[{ }^{3} \mathrm{H}\right]$-befunolol to microsomal fractions from the guinea-pig taenia caecum in the presence or absence of $\operatorname{Gpp}(\mathrm{NH}) p$ $100 / \mathrm{M}$. Figures $6 \mathrm{~B}$ and $6 \mathrm{C}$ show typical Scatchard plots (17) of the specific $\left[{ }^{3} \mathrm{H}\right]$ befunolol binding to microsomal fractions in the presence (Fig. 6C) or absence (Fig. 6B) of $\mathrm{Gpp}(\mathrm{NH}) \mathrm{p} 100, a \mathrm{M}$. In the absence of $\mathrm{Gpp}(\mathrm{NH}) \mathrm{p}$, this binding data showed two affinity sites of the receptor by the iterative nonlinear regression analysis: one of high $\left(K_{11}\right)$ affinity and one of low affinity $\left(K_{\mathrm{I}}\right)$. The dissociation constants $\left(K_{\mathrm{T}}\right)$ and the maximum binding sites $\left(B_{\max }\right)$ are shown in Table 1. In the presence of $\operatorname{Gpp}(\mathrm{NH}) \mathrm{p}$, this binding data showed the high affinity site of the receptor. The dissociation constant $\left(K_{D}\right)$ and the maximum binding site $\left(B_{\max }\right)$ are shown in Table 1.

The intrinsic activity, $\mathrm{pD}_{2^{-}}, \mathrm{pA}_{2^{-}}, \mathrm{pK}_{\mathrm{A}^{-}}$, $p K_{i}$ - and $p K_{D}$-values of befunolol are summarized in Table 2. In the absence of $\mathrm{Gpp}(\mathrm{NH}) \mathrm{p}$. the negative log of the dissociation constant of the high affinity site, $p K_{D}$ (High)-value of befunolol, was in agreement with its $\mathrm{pA}_{2}$-value obtained in the mechanical response and that of the low affinity site, $\mathrm{pK}_{\mathrm{p}}$ (Low)-value of befunolol, was in agreement with its $p D_{2}$-value obtained in the mechanical response or $\mathrm{pK}_{\mathrm{A}}$-value abtained with photoaffinity labeling. In the presence of $\operatorname{Gpp}(\mathrm{NH}) \mathrm{p}$, the negative log of the dissociation constant, $\mathrm{pK}_{\mathrm{D}}$-value of befunolol, was also in agreement with its $\mathrm{pA}_{2}$-value obtained in the mechanical response.

Table 1. The dissociation constants $\left(K_{D}\right)$ and the maximum binding sites ( $B$ max $)$ of $\left[{ }^{3} H\right]$-befunolol to microsomal fractions from guinea-pig taenia caecum in the presence of absence of $100 \% \mathrm{M} \mathrm{Gpp}(\mathrm{NH}) \mathrm{p}$

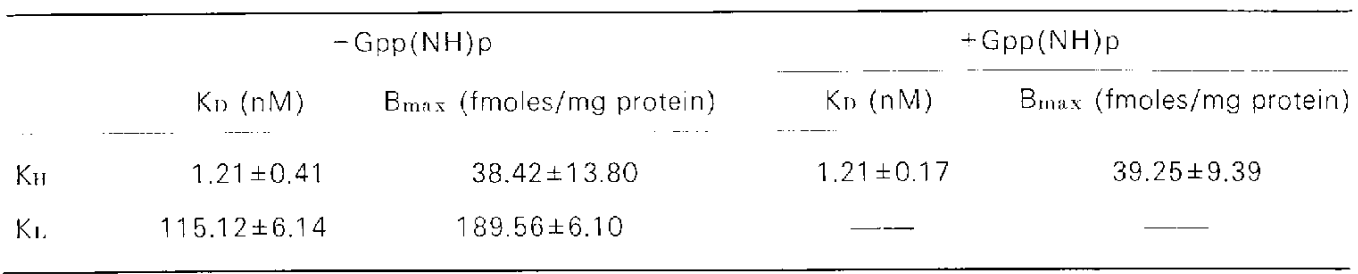

Ki1: high affinity site. Ki.: low affinity site. Each value is presented as a mean \pm S.E. of a triplicate determination in each of 3 experiments. 


\section{A}
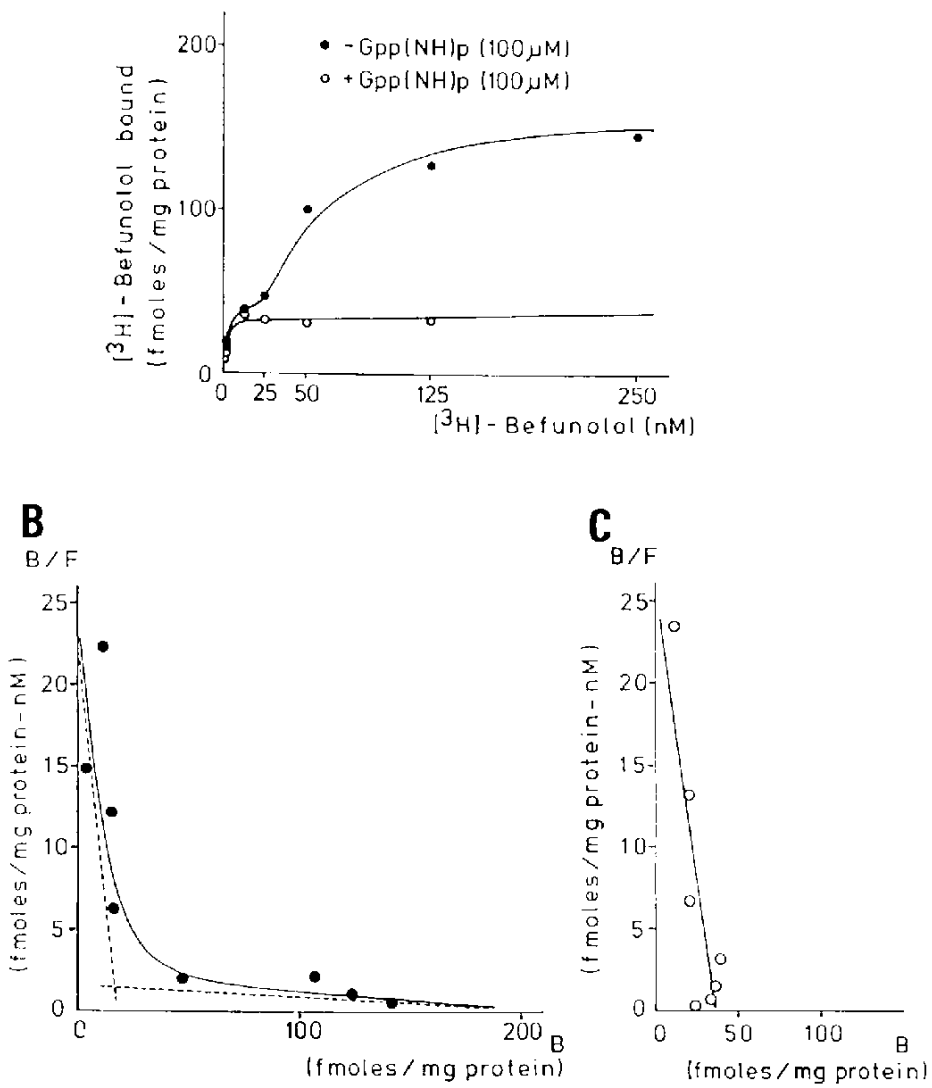

Fig. 6. (A) Typical specific $\left[{ }^{3} \mathrm{H}\right]$-befunolol binding with increasing concentrations of $\left[{ }^{3} \mathrm{H}\right]$-befunolol to microsomal fractions from the guinea-pig taenia caecum in the presence or absence of $\mathrm{Gpp}(\mathrm{NH}) \mathrm{p}$. Abscissa: concentration (nM) of $\left[{ }^{3} \mathrm{H}\right]$-befunolol and ordinate: $\left[{ }^{3} \mathrm{H}\right]$-befunolol (bound), fmoles/mg protein. (B) Typical Scatchard plot of the deta in the absence of $G p p(N H)$. The hyperbola (the so'id line) and the two asymptotes (the dotted lines) were obtained by nonlinear regression analysis. It was shown that two types of binding sites are present. For detals on the methods of analysis used. see Materials and Methods. Abscissa: concentration of [ $\left.{ }^{3} \mathrm{H}\right]$-befunolol (bound). fmoles/mg protein and ordinate: the ratio of bound- to free- $\left[{ }^{3} \mathrm{H}\right]$-befunolol found in the incubation medium. (C) Typical Scatchard plot of the data in the presence of $\mathrm{Gpp}(\mathrm{NH}) \mathrm{p}$. The line was obtained by nonlinear regression analysis. For details on the methods of analysis used, see Materials and Methods. Abscissa: concentration of $\left[{ }^{3} \mathrm{H}\right]$-befunolol (bound), fmoles/mg protein and ordinate: the ratio of bound-to free$\left[{ }^{3} \mathrm{H}\right]$-befunolol found in the incubation medium.

\section{Discussion}

Befunolol was found to be a typical partial agonist since intrinsic activities were 1.0 for isoprenalıne, a full agonist, and $0.28 \pm 0.03$ for befunolol, and the dose-response curve of isoprenaline was parallelly shifted by befunolol. As the partial agonist generally has little receptor reserve, its $\mathrm{pD}_{2}$-value must be equal to its $p A_{2^{-}}, p K_{A^{-}}$and $p K_{i}$-values.
However, the $\mathrm{pD}_{2}$-value of befunolol was equal to its $p K_{A}-$ value, but not to its $p_{2_{2}-\text { or }}$ $p K_{i}$-value. These results are in good agreement with our previous findings (4-6), and the most probable explanation for our observation would seem to be as follows: The full agonist, partial agonist and antagonist interact with the same $\beta$-adrenoceptor where there may be two different sites: one binding site for agonistic action 
Table 2. The intrinsic activity, $p \mathrm{D}_{2^{-}}, p \mathrm{~A}_{2}{ }^{-}, p \mathrm{~K}_{1}-\mathrm{pK_{1 } - \text { and }} \mathrm{pK} \mathrm{K}_{\mathrm{r}-\mathrm{value}}$ of befunolol tested on guinea-pig taenia caecum

\begin{tabular}{|c|c|c|c|c|c|c|c|}
\hline \multirow{2}{*}{\multicolumn{3}{|c|}{$\begin{array}{l}\text { From } \\
\text { mechanical responses: } \\
\text { (Befunolol) }\end{array}$}} & \multirow{2}{*}{$\begin{array}{l}\text { From } \\
\text { photoafunity } \\
\text { labelıng: } \\
\text { (Befunolol) }\end{array}$} & \multirow{2}{*}{$\begin{array}{l}\text { From } \\
\text { inhibition } \\
\text { curvel } \\
\text { (Befunolol) }\end{array}$} & \multicolumn{3}{|c|}{$\begin{array}{l}\text { From } \\
\text { binding assay } \\
\left(\left[{ }^{3} \mathrm{H}\right] \text {-befunolol) }\right.\end{array}$} \\
\hline & & & & & \multicolumn{2}{|c|}{$-\operatorname{Gpp}(\mathrm{NH}) p$} & $+G p p(N H) p$ \\
\hline i.a. & $\mathrm{pD}_{2}$ & $\mathrm{pA}_{2}$ & $p K i$ & $p K_{i}$ & $\begin{array}{l}p K_{1} \\
(L O W)\end{array}$ & $\begin{array}{c}\bar{p} K_{1} \\
(H i g h)\end{array}$ & $p K_{1}$ \\
\hline $0.28 \pm 0.03$ & $7.06 \pm 0.16$ & $9.22 \pm 0.10$ & $6.88 \pm 0.32$ & $9.17 \pm 0.13$ & $6.94 \pm 0.02$ & $8.97 \pm 0.14$ & $8.96 \pm 0.07$ \\
\hline
\end{tabular}

\begin{abstract}
i.a.: intrinsic activity, ": mean $\pm S . E$. of 6 experiments, $"$ : mean $\pm S$. E. of 4 separate experiments, $:$ mean $\pm S . E$. of 3 separate experiments. The pKi-value was reprosented as the negative log of the dissociation constant $\left(K_{i}\right)$ which was estimatod from the inhibition curve of $\left[{ }^{3} \mathrm{H}\right]$-dinydroalprenolol binding to microsomal fractions. The pKr-value was represented as the negative log of the dissociation constant (KD) which was estimated from the Scatchard plot of the $\left[{ }^{3} \mathrm{H}\right]$-befunolol binding to microsomal fractions in the presence or absence of $100 \mu \mathrm{M} \mathrm{Gpp}(\mathrm{NH}) \mathrm{p}$.
\end{abstract}

and the other site for antagonistic action. Both the binding sites are supposed to produce mutual exclusion through unknown mechanisms.

On the other hand, guanine nucleotides play an important role in the process subsequent to an agonist-receptor interaction (8). It has been reported that in the presence of GTP, the affinity of various receptors for agonist are decreased (18-22). For the $\beta$-adrenoceptor, this effect of GTP has been described as "agonist-specific". as it is seen with agonists but not with antagonists $(19,21,23)$. In this study, the Scatchard plot of the specific $\left[{ }^{3} \mathrm{H}\right]$ befunolol binding showed two affinity sites of the receptor in the absence of $G p p(N H) p$. However, in the presence of $G p p(N H) p$. the low affinity site was reduced and the high affinity site was not affected. It is thought that in the presence of $\operatorname{Gpp}(\mathrm{NH}) \mathrm{p}$, the affinity of the low affinity site did not disappear, but was too low to determine its dissociation constant $\left(K_{1}\right)$ and maximum binding site $\left(\mathrm{B}_{\max }\right)$. Moreover, the $p K_{D^{-}}$ value of the high affinity site of befunolol was in agreement with its $\mathrm{pA}_{2}$-value, and that of the low affinity site was in agreement with its $\mathrm{pD}_{2}$-value or $\mathrm{pK}_{\mathrm{A}}$-value. These results suggest that the low affinity site may be an agonist binding site and the high affinity site, an antagonist binding site, and that the $\beta$-adrenergic partial agonist may interact with two different sites: the agonist binding site (the low affinity site) and the antagonist binding site (the high affinity site). Since an antagonist binding site is regarded as a high affinity site, it is thought that it is easy for the $\beta$-adrenergic partial agonist to interact with the high affinity site, the antagonist binding site. However, our results suggest that the $\beta$-adrenergic partial agonist is able to interact with the low affinity site by increasing the concentrations of the $\beta$-adrenergic partial agonist, even though the $\beta$-adrenergic partial agonist interacts with the high affinity site. The $\beta$-adrenergic partial agonist may interact simultaneously with the high affinity site and the low affinity site, but supposing from the results of the mechanical responses, it is difficult to induce agonistic action when the $\beta$-adrenergic partial agonist interacts with the high affinity site (the antagonist binding site) and difficult to induce antagonistic action when the $\beta$-adrenergic partial agonist interacts with the low affinity site (the agonist binding site). These findings support our previous observations (4-6). Since the classical receptor theory seems to require a modification in the cholinergic receptor (24) or histamine receptor $(25,26)$, much additional experimental support of $\beta$-adrenoceptors in the guinea-pig taenia caecum is necessary.

Acknowledgements: The authors thank Kaken Pharmaceutical Company for the generous supply of $\left[{ }^{3} \mathrm{H}\right]$-befunolol. 


\section{References}

1 Stephenson, R.P.: A modification of receptor theory. Br. J. Pharmacol. 11, 379-393 (1956)

2 Ariëns, E.J., van Rossum, J.M. and Koopman, P.C.: Receptor reserve and threshold phenomena 1. Theory and experiments with autonomic drugs tested on isolated organs. Arch. Int. Pharmacodyn. Ther. 127, 459-478 (1960)

3 Arièns, E.J.: Molecular Pharmacology. Academio Press, New York (1976)

4 Takayanagi, I. and Koike, K.: A possible mechanism of action of a beta-adrenergic partial agonist (carteolol) in guinea pig taenia caecum. J. Pharmacobiodyn. 6. 56-59 (1983)

5 Koike, K. and Takayanagi, I.: Interaction of $\beta$ adrenergic partal agonist with its receptor in guinea-pig taenia caecum. Gen. Pharmacol. 15. 47-50 (1984)

6 Takayanagi, I., Koike, K. and Sato, T.: Interactions of some partial agonists with beta-adrenoceptor in the isolated taenia caecum and tracheal smooth muscle of guinea pig. Japan. J. Pharmacol. 35, 301-305 (1984)

7 Zahniser, N.R. and Molinoff. P.R.: Fffect of guanine nucleotides on striatal dopamine receptor. Nature 275, 453-455 (1978)

8 Rodbell, M.: The role of hormone receptors and GTP-regulatory proteins in membrane transduction. Nature 284, 17-22 (1980)

9 Van Rossum, J.M.: Cumulative dose-response curve II. Techniques for the making of dose rosponse curve in isolated organs and evaluation of drug parameters. Arch. Int. Pharmacodyn. Ther. 143, 299-330 (1963)

10 Takayanagi, I., Yoshioka, M., Takagi, K. and Tamura, Z.: Photoaffinity labeling of the $\beta$ adrenergic receptors and receptor reserve for isoprenaline. Eur. J. Pharmacol. 35, 121-125 (1976)

11 Koike, $K$. and Takayanagi, I.: Relationship between intrinsic activity of $\beta$-adrenoceptor agonist and amount of spare receptors in guinea pig taenia caecum. Japan. J. Pharmacol. 33, $327-333(1983)$

12 Furchgott, R.F.: The use of $\beta$-haloalkylamines in the differentialion of receptors and the determirlation of dissociation constants of receptor agonist complexes. Adv. Drug Res. 3, 21-55 (1966)

13 Takayanagi, I., Hongo, T., Hisayama, T. and Kasuya, $Y$.: Effects of acety!choline and histamine on mechanical activity of rabbit tacnia coli, Caincorporation and Ca-release ir its microsomal fractions. J. Pharmacobiodyn. 2, 212-218 (1979)
14 Lowry, O.H., Rosebrough, N.J., Farr, A.L. and Randall. R.J.: Protein measurcment with the Folin phenol reagent. J. Biol. Chem. 193, ?65275 (1951)

15 Kubokawa, K.: Chemical equilibrium (Scatchard plot). In Practical Program Library. Edited by Ishii, S., Kouno, S., Wakabayashi, K., Wada, M. anó Kubokawa, K., p. 93-109. Baifukan. Tokyo (1983)

16 Cheng, Y.-C. and Prusoff, W.H.: Relationship between the inhibition constant $\left(K_{i}\right)$ and the concentration of inhibitor which causes $50 \%$ inhibition (IC50) of an enzymatic reaction. Biochem. Pharmacol. 22, 3099-3108 (1973)

17 Scatchard, G.: The attractions of proteins for small molecules and ions. Ann. N.Y. Acad. Sci. 51, 660-672 (1949)

18 Rodbell, M., Krans, H.M.J., Pohl, S.L. and Birnbaumer, L.: The glucagon-sensitive adenyl cyclase system in plasma membranes of rat liver IV. Effects of guanyl nucleotides on binding of ${ }^{125} \mathrm{l}$-glucagon. J. Biol. Chem. 246, 1872-.1876 (1971)

19 Maguire, M.E., Van Arsdale, P.M. and Gilman, A.G.: An agonist-specific effect of guanine nucleotides in binding to the beta adrenergic receptor. Mol. Pharmacol. 12, 335-339 (1976)

20 Lefkowitz, R.J., Mullikin, D., Wood, C.L., Gore, T.B, and Mukherjee, C.: Regulation of prostaglancin receptors by prostaglandins and guanine nucleotides in frog erythrocytes. J. Biol. Cher. 252, 5295-5303 (1977)

21 Williams, L.T. and Lefkowitz, R.J.: Slowly reversible binding of catecholamine to a nucleotide-serisitive state of the $\beta$-adrenergic receptor. J. Biol. Chem. 252, 7207-7213 (1977)

22 Blume, A.J.: Interaction of ligands with the opiate receptors of b'ain membranes: Regulation by ions and nucleotides. Proc. Natl. Acad. Sci. U.S.A. 75, 1713-1717 (1978)

23 Wiemer, G., Wellstein, A., Palm, D., von Hattingberg. H.M. and Brockmeier, D.: Properties of agonist binding at the $\beta$-adrenoceptor of the rat reticulocyte. Naunyn Schmiedebergs Arch. Pharmacol. 321, 11-19 (1982)

24 Moran, J.F. and Triggle, D.J.: Approaches to the quantitation and isolation of pharmacological recoptors. In Fundamental Concepts of DrugReceptor Interaction, Edited by Danielli. J.F.. Moran, J.F. and Triggle. D.J.. p. 133-176. Academic Press, New York (1970)

25 Van den Brink, F.G. and Lien, E.J.: Competitive and non-competitive anlagonism. In Handbook of Experimental Pharmacology, Edited by Rocha e Silva. M.. Vol. 18, p. 333-367. Springer- 
Verlag. Berlin (1978)

26 Cook, D., Iwanow, D., Kenakin, T. and Krueger, D.: Irreversible blockade of responses to a partial agonist acting at the histamine $\mathrm{H}_{7}$-receptor. Eur. J. Pharmacol. 77, 125-129 (1982) 